\section{Investigation and Prevention of Cork Spot Disorder in 'Akizuki' Pear (Pyrus pyrifolia Nakai)}

\author{
Yan-xin Duan, Ying Xu, Ran Wang, and Chun-hui Ma ${ }^{1}$ \\ College of Horticulture, Qingdao Agricultural University, Qingdao 266109, \\ China
}

Additional index words. calcium, cork spot, prohexadione calcium, pear

\begin{abstract}
Akizuki' (Pyrus pyrifolia Nakai) is a dominant Asian pear cultivar with gradually increasing cultivation area in Shandong province. However, this cultivar is found susceptible to cork spot disorder in recent years. In this study, we explored the physiological-biochemical mechanism of cork spot disorder in pear fruit, and investigated the effectiveness of spraying calcium (Ca), boron (B) solution or prohexadione calcium (P-Ca) on cork spot incidence. Cork spotted fruit had the characteristics of significantly larger fruit size with shorter fruit pedicels. Compared with normal fruit, cork spotted fruit had lower content of total soluble solids, soluble and reducing sugar, and vitamin $\mathrm{C}$. In addition, cork spotted fruit accumulated much higher levels of $\mathrm{N}$ and $\mathrm{Mg}$, and lower levels of $\mathrm{K}$ and $\mathrm{P}$. However, $\mathrm{Ca}$ deficiency was not observed in cork spotted fruit, on the contrary, we determined high concentrations of $\mathrm{Ca}$ and free $\mathrm{Ca}^{2+}$ in disordered fruit. At the same time, the ratios of $\mathrm{K} / \mathrm{Ca}, \mathrm{Mg} / \mathrm{Ca}$, and $(\mathrm{K}+\mathrm{Mg}) / \mathrm{Ca}$ were significantly lower in cork spotted fruit as compared with normal fruit. Among all treatments, spraying with 3500 times dilution of P-Ca at 15-day intervals from 30 to 90 days after full bloom showed promise for reducing cork spot incidence in 'Akizuki' pear without affecting fruit quality attributes. This research herein reveals the physiologicalbiochemical characteristic of cork spot disorder, and implicates P-Ca as a potential tool to reduce cork spot incidence in Asian pear cultivar Akizuki.
\end{abstract}

'Akizuki' (Pyrus pyrifolia Nakai), a Japanese pear, plays an important role in pear production in China because of its good quality characteristics such as large fruit, pretty shape, delicate pulp. and high soluble solid content. However, with the cultivation area increasing, a physiological disorder that appears to be cork spot in this cultivar has occurred in several pear orchards in Shandong province of China, and become a serious problem over the years.

Cork spot, bitter pit, and corky core, the most typical physiological disorders that develop in apple fruit skin, are commonly called cork spot-like physiological disorder (CSPD) (Faust and Shear, 1968; Ferguson and Watkins, 2011). In pear fruits, cork spot is also the most common physiological disorder except for hard end, corky core, and water core (Inomata et al., 1993; Lu et al., 2014). Except for 'Akizuki', this disorder is also frequently found in other pear varieties such as 'Anjou', 'Alexander Lucas', and 'Oushuu' pear (Hayama et al., 2017; Raese and Drake, 1993; Richardson and Lombard, 1979; Tomala and Trzak, 1994). Cork spot-

\footnotetext{
Received for publication 29 Nov. 2018. Accepted for publication 10 Jan. 2019.

This work was funded by the Key Research and Development Program of Shandong Province (2017CXGC0209), the China Agricultural Research System (CARS-29-07), and the subproject of Key National R\&D Programs (2018YFD1000204).

${ }^{1}$ Corresponding author. E-mail: machunhui2000@ 163.com.
}

like disorder involves the suberization of cells in pear flesh (Tamura, 2017). A recent report indicated that cork spot symptoms were observed more markedly in the late maturing fruit in 'Akizuki' pear (Hayama et al., 2017). In addition, the severity of the cork spot disorder showed an association with the fruit fresh weights: more cork spots appeared on larger fruit (Hayama et al., 2017). Moreover, more cork spots were observed in the middle of the fruit, with few at the stem end (Hayama et al., 2017).

Many physiological disorders are closely related to $\mathrm{Ca}$ deficiency in fruit, and control of these physiological disorders requires maintenance of adequate levels of $\mathrm{Ca}$ (Dong et al., 2015; Lee et al., 2007; Miqueloto et al., 2014; Raese, 1988; Raese and Drake 1995). Cork spot presented symptoms similar to those of bitter pit, was induced by Ca deficiency, and, thus, Ca spraying was a useful alleviating measure (Faust and Shear, 1969; Raese and Drake, 1993, 1995, 2006; Richardson and Lombard, 1979). Besides $\mathrm{Ca}$, the levels of other mineral nutrients could also influence fruit susceptibility to calcium deficiency disorders (Lee et al., 2007). For example, $\mathrm{K}$ and $\mathrm{Mg}$ can antagonize the uptake or the function of $\mathrm{Ca}$ at the membrane or compete with $\mathrm{Ca}$ at active site on membranes (Schönherr and Bukovac, 1973; Yermiyahu et al., 1994). High levels of $\mathrm{N}$ in the fruit have been reported to aggravate the development of Ca deficiency symptoms in apple (Bangerth, 1974; Shear, 1971). However, there are also some conflicts, for example, Mason and Welsh (1970) showed that fruits with bitter pit or cork spot had higher $\mathrm{Mg}$ concentration than normal fruits, whereas Woodbridge (1971) found no significant differences between them. Therefore, the nutrient concentration ratios such as $\mathrm{K} / \mathrm{Ca}, \mathrm{Mg} / \mathrm{Ca}$, and $(\mathrm{K}+\mathrm{Mg}) / \mathrm{Mg}$ are more meaningful to predict $\mathrm{Ca}$ deficiency disorders than total fruit $\mathrm{Ca}$ concentration alone (Dris et al., 1998; Freitas et al., 2010; Lanauskas and Kvikliené, 2006; Schumacher and Fankhauser, 1970). Although the association between cork spot and mineral concentrations in European pear has been frequently reported, little has been done on Asian pear cultivars.

Prohexadione calcium (P-Ca) inhibits the biosynthesis of gibberellin (Evans et al., 1999; Rademacher et al., 2004). Compared with other three triazole growth inhibitors, $\mathrm{P}-\mathrm{Ca}$ has low toxicity and limited persistence in the environment, being metabolized or decomposed 6 to 7 weeks after application (Evans et al., 1999; Owens and Stover, 1999; Rademacher et al., 2004). Previous studies have demonstrated significant control of shoot growth by $\mathrm{P}-\mathrm{Ca}$ on a range of pear varieties (Asín et al., 2007; Costa et al., 2001; Einhorn et al., 2014; Elfving et al., 2003; Hawerroth et al., 2012), and P-Ca has little effect on fruit quality attributes in pear (Costa et al., 2004; Einhorn et al., 2014; Elfving et al., 2003). Moreover, P-Ca was reported to induce resistance to apple scab and fire blight (Costa et al., 2001; Römmelt et al., 1999). However, whether P-Ca has potential to reduce cork spot incidence in 'Akizuki' pear has not been studied.

The goals of our study were to elucidate the difference of fruit characteristics and content of mineral elements between cork spotted and normal fruits in 'Akizuki' pear, and to determine an effective spray material for reducing the incidence of cork spot without affecting fruit quality attributes.

\section{Materials and Methods}

Plant materials. Six-year-old 'Akizuki' pear trees grown on Pyrus betulaefolia Bunge pear rootstocks were selected for the experiment. The orchard, trained to a trellis cultivation system, with spacing of $4 \times 3 \mathrm{~m}$, was located in Qingdao City, Shandong Province, People's Republic of China. Cork spotted and normal fruits in this same orchard were collected at maturity, $140 \mathrm{~d}$ after full bloom (DAFB) in 2014-16. Whole fruit flesh tissues were divided into three parts (the calyx end, the middle part, and the stem end) with the core and seeds excluded, and then were sliced and immediately frozen in liquid nitrogen and maintained at $-70{ }^{\circ} \mathrm{C}$ for further study.

Performance of exogenous $\mathrm{Ca}, \mathrm{B}$, and $P-C a$ treatments. Ca, B, P-Ca (Kumiai Chemical Industry Co., Ltd, Tokyo, Japan), or unsprayed control were used in this experiment. Each treatment was randomly allocated to three trees selected by uniformity and size (canopy volume), making five replications for each. All treatments were conducted every $15 \mathrm{~d}$, with a total of five replications from 
beginning at 30 DAFB. When spraying, $\mathrm{H}_{3} \mathrm{BO}_{3}$ and $\mathrm{Ca}\left(\mathrm{NO}_{3}\right)_{2}$ were diluted 600 times with water, and P-Ca was diluted 1500, 2500, and 3500 times with water, respectively. Fruit samples from the treated and control trees were harvested at commercial maturity (140 DAFB) and subsequently transported to the laboratory within a period of $2 \mathrm{~h}$, and then used for fruit quality evaluation. Effects on cork spot incidence were assessed on fruits, and data were expressed as percentage of the number of disordered fruit divided by the total number of fruit.

Fruit quality analysis. Fruit firmness was determined by removing fruit skin on four sides of each fruit, using a texture analyzer (CT3; Brookfield, Middleboro, MA) with a 2$\mathrm{mm}$-diameter probe, $10-\mathrm{mm}$ penetration depth, and $0.5-\mathrm{mm} \cdot \mathrm{s}^{-1}$ penetration rate, expressed in $\mathrm{kg} \cdot \mathrm{cm}^{-2}$.

Average fruit weight was determined by sampling and individually weighing 200 fruits randomly chosen from all trees per treatment. The vertical and horizontal diameter of fruit, the length and diameter of fruit pedicel, and the calyx concave depth were measured by vernier caliper.

To measure the total soluble solids, the sample of the stem end, the middle part, and the calyx end of fruit was juiced, respectively, placed on the prism of a digital handheld Abbe-type refractometer and expressed as ${ }^{\circ}$ Brix. Titratable acidity of different fruit parts was measured using titration with $0.1 \mathrm{~N}$ sodium hydroxide $(\mathrm{NaOH})$ and calculated as a malic acid equivalent. The content of vitamin $\mathrm{C}$, soluble sugar and starch, and reducing sugars was determined by colorimetry by molybdenum blue method, anthrone reagent method, and a 3, 5-dinitrosalicylic acid colorimetric method, respectively.

Measurement of the mineral nutrient content. Fruit flesh tissues were dried in an oven at $105^{\circ} \mathrm{C}$ for $30 \mathrm{~min}$, and then at $75^{\circ} \mathrm{C}$ until a constant weight was achieved; $0.5 \mathrm{~g}$ of flesh tissues was mixed with $2 \mathrm{~mL}$ perchloric and $10 \mathrm{~mL}$ nitric acids. After digestion and dissolution, the total contents of $\mathrm{Ca}, \mathrm{Mg}$, $\mathrm{K}, \mathrm{Fe}, \mathrm{Zn}$, and $\mathrm{P}$ were analyzed by using an ICP-OES optima 8000 (PerkinElmer Inc., Waltham, MA).

For the determination of total $\mathrm{N}$ content, $1 \mathrm{~g}$ of dried flesh samples was mixed with $0.3 \mathrm{~g}$ $\mathrm{CuSO}_{4}, 3 \mathrm{~g}$ anhydrous $\mathrm{Na}_{2} \mathrm{SO}_{4}$, and 10 to $12 \mathrm{~mL}$ concentrated $\mathrm{H}_{2} \mathrm{SO}_{4}$. After digestion and dissolution, the $\mathrm{N}$ content was assayed using a Kjeldahl nitrogen apparatus (K9860; Hanon instruments Co., Ltd., Jinan, China).

Observation of $\mathrm{Ca}^{2+}$ localization. The localization of free $\mathrm{Ca}^{2+}$ was observed by fluorescence imaging as previously described by Qu et al. (2012), with some modifications. Thin slices of flesh were collected from the same region under the peel tissue of normal and cork spot fruit by using a razor blade. The flesh tissues were initially washed twice with HEPES buffer solution, which were loaded with fluo-4/AM supplemented with $25 \%$ Pluronic F-127 and then subsequently washed three times with HEPES buffer solution. After maintaining the tissue in the dark


Fig. 1. Symptoms of 'Akizuki' pear fruit with cork spot. (A) Fruit with light cork spot. (B) Longitudinal section of fruit with light cork spot. (C) Fruit with severe cork spot. (D) Longitudinal section of fruit with severe cork spot. (E, F) Endogenic type or subcutaneous of suberized tissue in pear fruit flesh, respectively.

at $37{ }^{\circ} \mathrm{C}$ for $1 \mathrm{~h}$, we visualized fluo-4 fluorescence (488-nm excitation laser light and 516-nm long-pass emission filter) using a laser scanning confocal microscope (TCS SP5 II; Leica, Wetzlar, Germany). The fluorescence results were analyzed using Image-Pro Plus software (Media Cybernetics, Rockville, MD).

Statistical analysis. The statistical analysis was performed using SPSS 17.0 software (IBM-SPSS, Armonk, NY). Data expressed as percentage were transformed by arcsine [square root $(n+1)]$ analysis. Sample means were compared using analysis of variance. Mean separation was determined by Duncan's multiple range test, and significance was tested at $5 \%$ or $1 \%$. Figures were composed using Microsoft Excel software (Redmond, WA).

\section{Results and Discussion}

Symptoms of cork spotted pear fruit. The symptoms of cork spot were observed more markedly in the late maturing fruit in 'Akizuki' pear, which is consistent with 
previous reports (Hayama et al., 2017; Mason and Welsh, 1970). At harvest stage, one or more small dark green or brown round dimpled spots of 0.3 to $1.0 \mathrm{~cm}$ in diameter were observed on the skin of disordered fruits, and below them was the affected brown spot (Fig. 1A and B). Much larger bumpy surface with necrotic flesh tissue under the affected area were observed with severe cork spotted fruits (Fig. 1C and D). Consistent with the report of Hayama et al. (2017), more cork spots were observed in the middle of the fruit (Fig. 1B and D). The brown spot could be anywhere between the skin and the core, but in most cases, it was close to the surface of the fruit just beneath the skin, which was similar to the report of Faust and Shear (1968). A depression developed above the internal spots as the fruit enlarged, due to the reduced growth in the affected tissues. With longitudinal cutting of the fruit, a localized desiccated tissue resembling cork was observed in the flesh of the fruit, which was brown and necrotic with dry and water-deficiency in vascular bundle tissue (Fig. 1E and F).

Comparison of fruit quality attributes between normal and cork spotted fruit. The average fruit weight of disordered fruit was significantly higher than that of normal fruit (Table 1), which is similar to the report of Hayama et al. (2017). The diameter of fruit pedicels and the calyx concave depth in disordered fruit were also significantly greater than that of normal ones (Table 1); however, total soluble solids in each part of disordered fruit was significantly lower than that in the same part of normal ones (Table 2). In addition, there was no significant difference in titratable acidity and fruit firmness with the exception of that in the calyx end (Table 2).

We also determined the contents of vitamin $\mathrm{C}$ and carbohydrates, including soluble sugar, reducing sugar, and starch of different fruits. From the calyx end to the stem end, the content of soluble and reducing sugar, and vitamin $\mathrm{C}$ in normal fruit were significantly higher than those of disordered fruit (Fig. 2). Inconsistent with the report of Li et al. (1999), the starch content in our research was much higher in cork spotted fruits than normal fruit, but the difference was not significant. All the results presented previously indicated that cork spotted pear fruit had larger fruit size and decreased the contents of total soluble solids, soluble and reducing sugar, and vitamin $\mathrm{C}$, which resulted in fruit quality deterioration.

Analysis of mineral nutrient content in normal and cork spotted pear fruit. Cork spot has been linked to fruit nutritional imbalance (Facteau et al., 2010; Richardson and Al-Ani, 1982; Tomala and Trzak, 1994). Mineral nutrient contents in the stem end, middle part, and calyx end of normal and disordered pear fruit were determined in this research. At the same time, the ratios of $\mathrm{K} / \mathrm{Ca}, \mathrm{Mg} / \mathrm{Ca}$, and $(\mathrm{K}+\mathrm{Mg}) / \mathrm{Ca}$ were also evaluated. Compared with normal fruit, 'Akizuki' pear with cork spot showed much higher N, significantly

Table 1. Fruit characteristic of cork spotted and normal 'Akizuki' fruits.

\begin{tabular}{|c|c|c|c|c|c|}
\hline Treatments & $\begin{array}{l}\text { Avg fruit } \\
\text { wt (g) }\end{array}$ & $\begin{array}{l}\text { Fruit shape } \\
\text { index }\end{array}$ & $\begin{array}{c}\text { Length of } \\
\text { fruit } \\
\text { pedicels }(\mathrm{cm})\end{array}$ & $\begin{array}{c}\text { Diam of } \\
\text { fruit } \\
\text { pedicels }(\mathrm{mm})\end{array}$ & $\begin{array}{l}\text { The calyx } \\
\text { concave } \\
\text { depth }(\mathrm{cm})\end{array}$ \\
\hline Normal fru & $453.76 \pm 27.66 \mathrm{~b}$ & $0.88 \pm 0.03 \mathrm{~b}$ & $2.23 \pm 0.47 \mathrm{a}$ & $3.40 \pm 0.27 b$ & $0.90 \pm 0.18 \mathrm{~b}$ \\
\hline Cork spotted & $517.49 \pm 36.77 \mathrm{a}$ & $0.89 \pm 0.03 \mathrm{a}$ & $1.42 \pm 0.23 \mathrm{~b}$ & $3.92 \pm 0.28 \mathrm{a}$ & $0.99 \pm 0.18 \mathrm{a}$ \\
\hline
\end{tabular}

$$
\text { fruit }
$$

Means followed by same letter(s) within a column are not significantly different by Duncan's multiple range test $(P<0.05)$.

Table 2. Fruit quality of cork spotted and normal 'Akizuki' fruits.

\begin{tabular}{llccc}
\hline Fruit type & Fruit parts & $\begin{array}{c}\text { Total soluble solids } \\
\left({ }^{\circ} \text { Brix }\right)\end{array}$ & $\begin{array}{c}\text { Titratable } \\
\text { acidity }(\%)\end{array}$ & $\begin{array}{c}\text { Flesh firmness } \\
\left(\mathrm{kg} \cdot \mathrm{cm}^{-2}\right)\end{array}$ \\
\hline Normal fruit & Stem end & $13.52 \pm 0.31 \mathrm{ab}$ & $0.89 \pm 0.02 \mathrm{a}$ & $8.56 \pm 0.94 \mathrm{~b}$ \\
& Middle & $13.91 \pm 0.40 \mathrm{a}$ & $0.89 \pm 0.01 \mathrm{a}$ & $9.17 \pm 0.75 \mathrm{~b}$ \\
& Calyx end & $13.47 \pm 0.28 \mathrm{ab}$ & $0.81 \pm 0.12 \mathrm{a}$ & $9.26 \pm 0.96 \mathrm{~b}$ \\
Cork spotted fruit & Stem end & $12.71 \pm 0.63 \mathrm{c}$ & $0.89 \pm 0.02 \mathrm{a}$ & $9.17 \pm 0.57 \mathrm{~b}$ \\
& Middle & $13.29 \pm 0.47 \mathrm{~b}$ & $0.90 \pm 0.01 \mathrm{a}$ & $9.06 \pm 0.95 \mathrm{~b}$ \\
& Calyx end & $12.62 \pm 0.58 \mathrm{c}$ & $0.89 \pm 0.01 \mathrm{a}$ & $12.2 \pm 1.15 \mathrm{a}$ \\
\hline
\end{tabular}

Means followed by same letter(s) within a column are not significantly different by Duncan's multiple range test $(P<0.05)$.
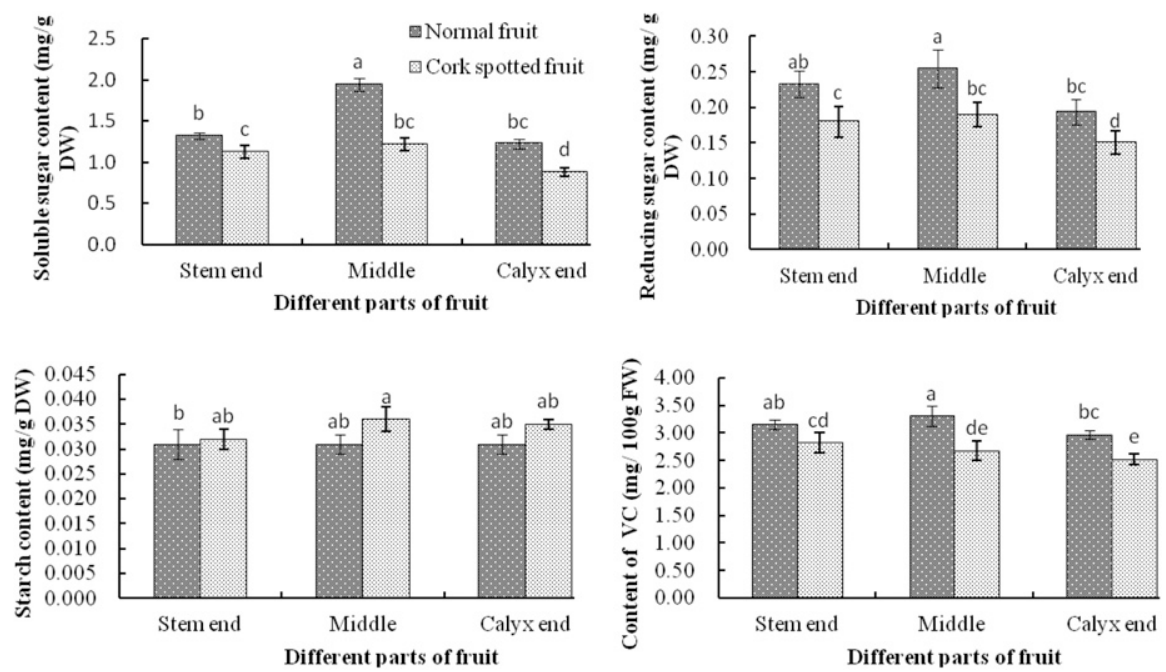

Fig. 2. Comparison of carbohydrate content of fruit flesh between cork spotted and normal 'Akizuki' pear. Error bars with different lowercase letters represent a statistical difference by Duncan's multiple range test $(P<0.05)$.

higher $\mathrm{Mg}$, and lower P content (Table 3). The results herein were not quite consistent with previous results, which showed significantly higher $\mathrm{Mg}$ and $\mathrm{P}$ in the spotted fruit (Faust and Shear, 1969; Tomala and Trzak, 1994). This conflict with $\mathrm{P}$ was probably due to the different cultivar or the cultivation conditions. The $\mathrm{K}$ content in the stem end and the middle part of normal fruit was significantly higher than those showing cork spot, which was in agreement with Al-Ani (1978), who found that low $\mathrm{K}$ in the fruit maybe related to the incidence of cork spot. Previous studies suggested that a high level of $\mathrm{N}$ reduces the movement of $\mathrm{Ca}$ toward the fruit (Ho et al., 1999) and triggers rapid fruit and cell expansion, which can potentially result in further dilution of the limited $\mathrm{Ca}$ content that moves into the fruit (Bar-Tal et al., 2001; Saure, 2001), and thus results in the occurrence of cork spot (Raese and Staiff, 1990). In our study, high levels of $\mathrm{N}$ correlated with cork spot in 'Akizuki' pear, but did not lead to $\mathrm{Ca}$ deficiency. Zn and Fe content seemed irrelevant to this disorder.

In some research, adequate $\mathrm{Ca}$ in fruit is necessary for controlling cork spot disorder in pears (Raese, 1989; Raese and Drake, 1995; Tomala and Trzak, 1994), but there is a report that indicated that cork spotted pear fruit had higher $\mathrm{Ca}$ concentrations than normal fruit (Mason and Welsh, 1970). However, our results showed that $\mathrm{Ca}$ concentration in all three parts of disordered 'Akizuki' pear fruit was much higher than those of normal fruit, especially for the middle and calyx end where the differences of $\mathrm{Ca}$ content were significant, suggesting that the occurrence of cork spot in this cultivar might not be due to a deficiency of total Ca (Fig. 3). $\mathrm{Mg}^{2+}$ and $\mathrm{K}^{+}$could compete with $\mathrm{Ca}^{2+}$ for binding sites at the plasma membrane; therefore, high levels of them reduced $\mathrm{Ca}$ absorption (Schönherr and Bukovac, 1973; Yermiyahu et al., 1994) and increased the susceptibility to Ca deficiency disorders (Askew et al., 1960). 
Table 3. Total mineral element content of cork spotted and normal 'Akizuki' fruits from the calyx to stem end.

\begin{tabular}{|c|c|c|c|c|c|c|c|}
\hline Fruit type & Fruit parts & $\mathrm{N}(\%)$ & $\mathrm{P}(\mathrm{mg} / \mathrm{kg})$ & $\mathrm{K}(\mathrm{mg} / \mathrm{kg})$ & $\mathrm{Mg}(\mathrm{mg} / \mathrm{kg})$ & $\mathrm{Zn}(\mathrm{mg} / \mathrm{kg})$ & $\mathrm{Fe}(\mathrm{mg} / \mathrm{kg})$ \\
\hline \multirow[t]{3}{*}{ Normal fruit } & Stem end & $4.00 \pm 1.35 \mathrm{c}$ & $1,654.51 \pm 24.28 \mathrm{a}$ & $11,917.83 \pm 341.26 \mathrm{ab}$ & $380.26 \pm 9.32 \mathrm{e}$ & $10.76 \pm 3.68 \mathrm{a}$ & $56.36 \pm 15.83 \mathrm{a}$ \\
\hline & Middle & $4.13 \pm 0.45 \mathrm{c}$ & $1,724.39 \pm 148.26 \mathrm{a}$ & $12,509.13 \pm 342.12 \mathrm{a}$ & $371.56 \pm 8.55 \mathrm{e}$ & $1.17 \mathrm{ab}$ & $52.99 \pm 7.65 b$ \\
\hline & Calyx end & $3.87 \pm 0.31 \mathrm{c}$ & $1,327.41 \pm 53.46 b$ & $11,685.07 \pm 494.39 \mathrm{ab}$ & $469.10 \pm 30.47 \mathrm{~d}$ & $2.16 \mathrm{ab}$ & $13.55 \mathrm{~b}$ \\
\hline \multirow[t]{3}{*}{ Cork spotted fruit } & Stem end & $5.10 \pm 0.89 b c$ & $637.18 \pm 12.74 \mathrm{~d}$ & $9,300.63 \pm 71.00 \mathrm{c}$ & $601.26 \pm 41.39 \mathrm{c}$ & $4.47 \pm 0.58 b$ & $45.78 \pm 15.26$ \\
\hline & Middle & $7.57 \pm 0.95 \mathrm{a}$ & $691.33 \pm 86.29 \mathrm{~cd}$ & $11,239.73 \pm 1,404.53 b$ & $695.67 \pm 86.66 b$ & $6.74 \pm 0.29 b$ & $28.36 \pm 8.42 b$ \\
\hline & Calyx end & $6.07 \pm 0.57 \mathrm{~b}$ & $817.66 \pm 44.63 \mathrm{c}$ & $12,669.00 \pm 318.06 \mathrm{a}$ & $815.34 \pm 1.97 \mathrm{a}$ & $6.12 \pm 1.15 \mathrm{~b}$ & $27.41 \pm 3.42 \mathrm{~b}$ \\
\hline
\end{tabular}

Different letters in the same column indicate significant differences by Duncan's multiple range test $(P<0.05)$.
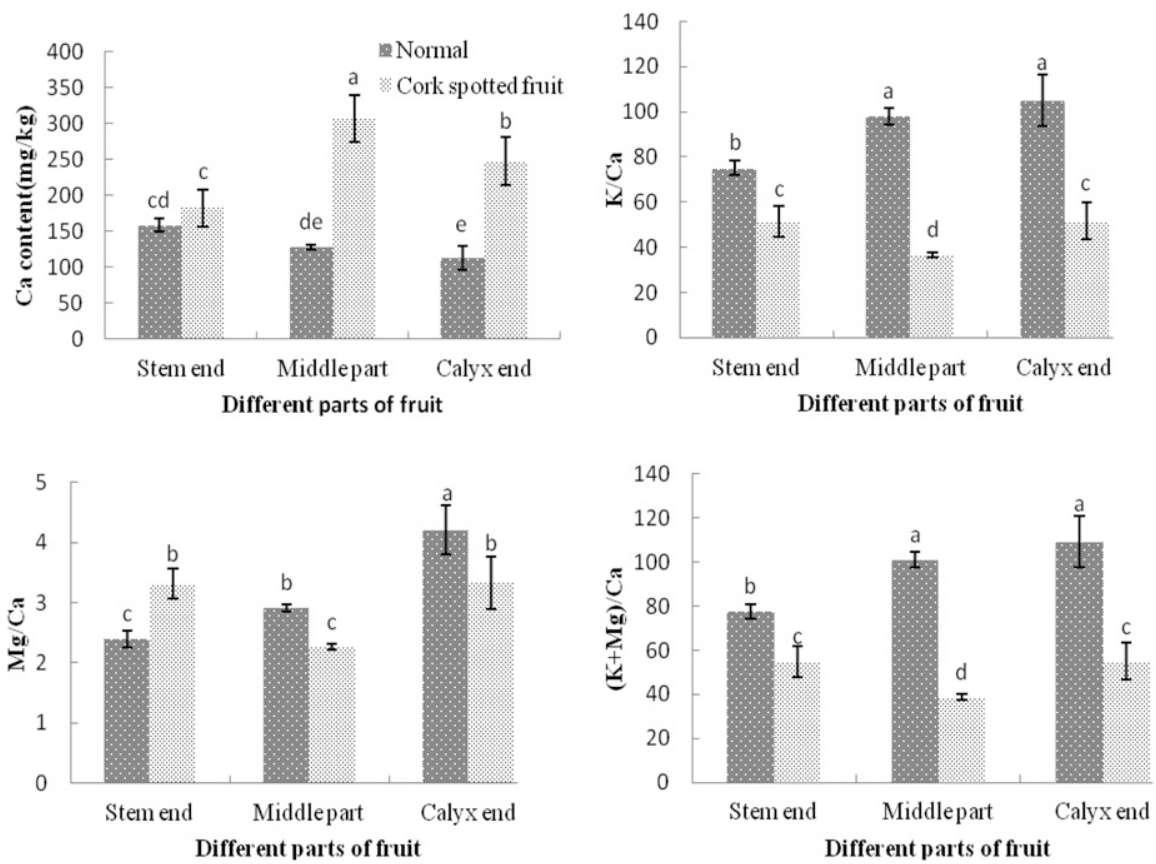

Fig. 3. The ratio of $\mathrm{K} / \mathrm{Ca}, \mathrm{Mg} / \mathrm{Ca},(\mathrm{K}+\mathrm{Mg}) / \mathrm{Ca}$, and $\mathrm{Ca}$ content in normal and cork spotted 'Akizuki' pear fruit. Error bars indicate SE from three replicates. Error bars with different letters represent a statistical difference by Duncan's multiple range test $(P<0.05)$.

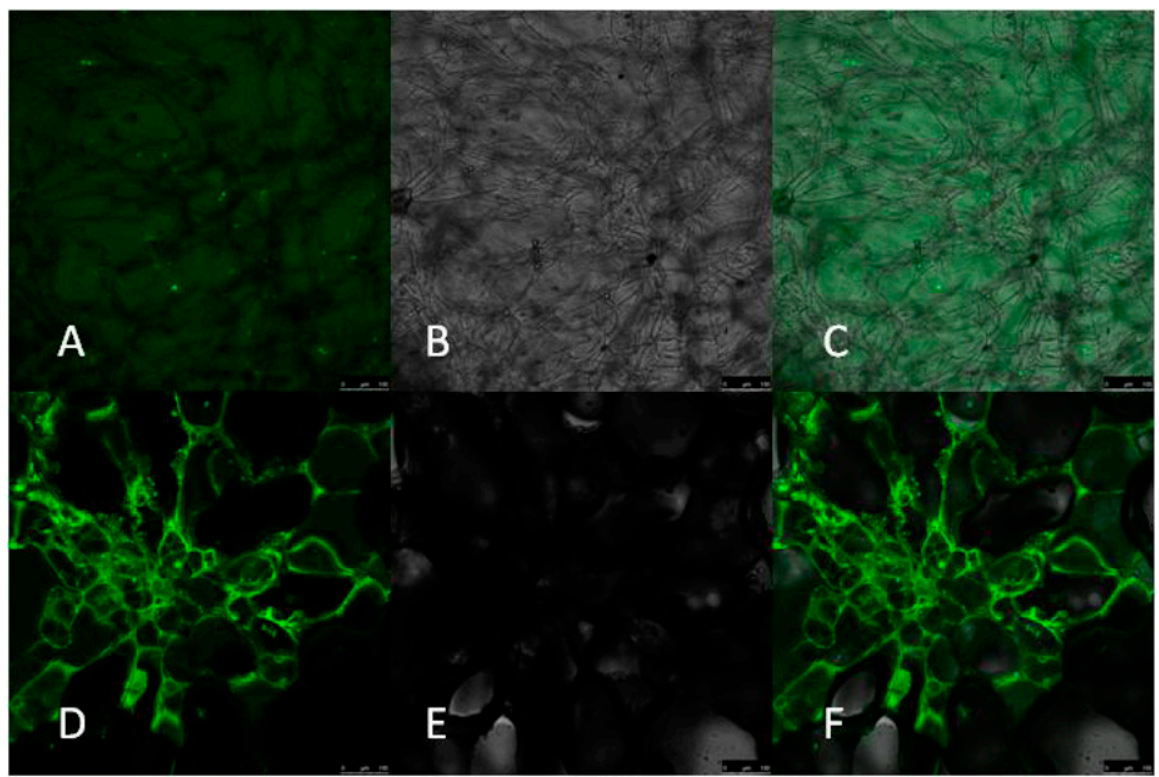

Fig. 4. Localization of free $\mathrm{Ca}^{2+}$ fluorescence signals in the flesh cells of normal and cork spotted 'Akizuki' pear. (A-C) Free $\mathrm{Ca}^{2+}$ fluorescence signals in normal fruits by Argon ion laser excitation (A), light field (B), and merge field (C). (D-F) Free $\mathrm{Ca}^{2+}$ fluorescence signals in cork spotted fruits by Argon ion laser excitation (D), light field (E), and merge field (F). Scale bar is $250 \mu \mathrm{m}$ for $(\mathbf{A}-\mathbf{C})$, and $100 \mu \mathrm{m}$ for (DF), respectively.
Therefore, it was more precise to use the ratios of $\mathrm{N} / \mathrm{Ca}, \mathrm{K} / \mathrm{Ca}$, and $\mathrm{Mg} / \mathrm{Ca}$ to predict $\mathrm{Ca}$ deficiency disorders than fruit total $\mathrm{Ca}$ concentration alone (Dris et al., 1998; Freitas et al., 2010; Lanauskas and Kvikliene, 2006). In our study, cork spot in 'Akizuki' pear was correlated with lower ratios of $\mathrm{K} / \mathrm{Ca}$, $(\mathrm{K}+\mathrm{Mg}) / \mathrm{Ca}$, and $\mathrm{Mg} / \mathrm{Ca}$ (Fig. 3). In addition, the most susceptible fruit part to cork spot (the middle part) not only accumulated significantly higher levels of $\mathrm{Mg}$ but also $\mathrm{Ca}$, whereas it had significantly lower K content. These conflicts may have resulted from the fruit development difference between Asian and European pears, because 'Akizuki' and 'Anjou' pears belong to Asian and European pear cultivars, respectively.

Analysis of the free $\mathrm{Ca}^{2+}$ localization in the flesh of cork spotted and normal pear fruit. At harvest, the free $\mathrm{Ca}^{2+}$ localization was detected in the flesh cells loaded with fluo-4/AM. High levels of free $\mathrm{Ca}^{2+}$ were observed in the cell wall and intercellular space of cork spotted fruit flesh; however, lower free $\mathrm{Ca}^{2+}$ spread over all of the flesh cells of normal fruit (Fig. 4). This cellular distribution difference of free $\mathrm{Ca}^{2+}$ between cork spotted and normal fruit may be a reason for cork spot. In addition, the free $\mathrm{Ca}^{2+}$ in the cork spotted fruit was much greater than normal fruit, which was in accordance with the results of total $\mathrm{Ca}$ content (Fig. 3), and partially consistent with the results of Wang et al. (2018), who suggested that the free $\mathrm{Ca}^{2+}$ localization in the flesh cells of hard end fruit was greater than that of normal fruit at harvest (120 DAFB), whereas it showed an opposite tendency during 'Whangkeumbae' pear fruit development (75-105 DAFB) (Wang et al., 2018).

Effect of exogenous treatments on the incidence of cork spot in 'Akizuki' pear. CSPD symptoms are reported to be induced by $\mathrm{Ca}$ or $\mathrm{B}$ deficiency, and the exogenous application of supplemental sprays containing these mineral nutrients improves the symptoms (Faust and Shear, 1968; Raese and Drake, 1995; Richardson and Lombard, 1979; Vang-Petersen, 1980). To prevent the incidence of cork spot in 'Akizuki' pear, five sprays at $30,45,60,75$, and 90 DAFB with different treatments $\left[\mathrm{H}_{3} \mathrm{BO}_{3}, \mathrm{Ca}\left(\mathrm{NO}_{3}\right)_{2}\right.$, and $\mathrm{P}-\mathrm{Ca}$ were adopted in this research. As expected, $\mathrm{Ca}, \mathrm{B}$, and $\mathrm{P}-\mathrm{Ca}$ treatments helped in controlling the cork spot in fruits from both axillary and spur bud (Fig. 5), which agreed with previous reports (Faust and Shear, 1968; Raese and Drake, 1993, 1995; Richardson and Lombard, 1979). However, the research of Matsumoto et al. (2018) indicated that 
none of $\mathrm{Ca}$ or $\mathrm{B}$ solutions decreased the CSPD incidence in 'Kurenainoyume' apple. In our research, we also observed higher levels of $\mathrm{Ca}$ and free $\mathrm{Ca}^{2+}$ in cork spotted fruit, indicating that deficiency of total $\mathrm{Ca}$ was not the major cause of this disorder in 'Akizuki' pear. But one consideration is why cork spot incidence could be inhibited by exogenous $\mathrm{Ca}$ solutions, because this disorder was not caused by lack of $\mathrm{Ca}$ ? It may be more meaningful to consider factors such as the existing state of $\mathrm{Ca}$ (soluble or insoluble) or the balance between $\mathrm{Ca}$ and other elements besides the hereditary factor, soil $\mathrm{pH}$, cultivation conditions, tree vigor, and the climate condition, which will affect the incidence of cork spot (Richardson and Lombard, 1979; Tamura, 2017).

There were significant differences in cork spot incidence of fruits from axillary bud between treatments and control, with the exception of $\mathrm{H}_{3} \mathrm{BO}_{3}$ (Fig. 5). The inhibitory effect of $\mathrm{Ca}\left(\mathrm{NO}_{3}\right)_{2}$ on cork spot was better than that of $\mathrm{H}_{3} \mathrm{BO}_{3}$, but there was no significant difference between them. Among the exogenous treatments, the most effective one was P-Ca sprayed with 3500 times dilution, which reduced the incidence of cork spot from $16.39 \%$ to $8 \%$ and from $15.87 \%$ to $6 \%$ in fruits from axillary and spur bud, respectively (Fig. 5). As is known, P-Ca has been widely used in the control of vegetative growth of several pear cultivars (Asín et al., 2007; Hawerroth et al., 2012; Pasa and Einhorn, 2014). 'Akizuki' pear shows a strong growth habit, from which new shoots stop growth $20 \mathrm{~d}$ later than other Asian pear cultivars, which may be correlated with its susceptibility to cork spot. Application of P-Ca alleviates the nutrition competition between fruit development and new shoot growth, which may have resulted in the prevention of cork spot incidence. In a word, P-Ca efficiently helped to reduce cork spot incidence in 'Akizuki' pear, thus providing a new control approach for cork spot in pear.

Effect of exogenous treatments on fruit quality in 'Akizuki' pear. To further test the effects of exogenous treatments on fruit quality in 'Akizuki' pear, we investigated the fruit characteristics of treated fruit and unsprayed control. The results showed that all exogenous treatments had no negative effects on fruit quality attributes, especially for fruit size (Table 4). Fruit quality attributes were unaffected by $\mathrm{P}-\mathrm{Ca}$, similar to that found for 'Anjou' (Einhorn et al., 2014), 'Bartlett' (Elfving, et al., 2003), 'Abate Fetel' (Costa et al., 2004), and 'Le Conte' (Carra et al., 2016); however, it was not in agreement with the results in which P-Ca sprayed fruits were much larger than control fruits (Costa et al., 2001), or reports in which $\mathrm{P}-\mathrm{Ca}$ has been reported to be associated with reduction of fruit size (Smit et al., 2005; Sugar et al., 2004). This may be due to the application time and concentration of P-Ca.

Furthermore, exogenous treatments helped to improve the development of fruit pedicels and the calyx concave: $\mathrm{Ca}\left(\mathrm{NO}_{3}\right)_{2}$ significantly


Different treatments

Fig. 5. Effect of exogenous treatments on cork spot incidence of fruit from axillary and spur bud in 'Akizuki' pear. Error bars with different letters represent a statistical difference by Duncan's multiple range test $(P<0.05)$.

Table 4. Effects of exogenous treatments on fruit characters of 'Akizuki' pear.

\begin{tabular}{lccccc}
\hline & Fruit wt $(\mathrm{g})$ & $\begin{array}{c}\text { Fruit shape } \\
\text { index }\end{array}$ & $\begin{array}{c}\text { Length of } \\
\text { fruit } \\
\text { pedicels }(\mathrm{cm})\end{array}$ & $\begin{array}{c}\text { Diam of } \\
\text { fruit } \\
\text { pedicels }(\mathrm{mm})\end{array}$ & $\begin{array}{c}\text { The calyx } \\
\text { concave } \\
\text { depth }(\mathrm{cm})\end{array}$ \\
\hline Control & $453.76 \pm 26.01 \mathrm{~A}$ & $0.88 \pm 0.03 \mathrm{~A}$ & $2.23 \pm 0.45 \mathrm{~A}$ & $3.40 \pm 0.26 \mathrm{BC}$ & $0.90 \pm 0.18 \mathrm{AB}$ \\
$\mathrm{H}_{3} \mathrm{BO}_{3}$ & $450.67 \pm 22.69 \mathrm{~A}$ & $0.86 \pm 0.05 \mathrm{~A}$ & $2.19 \pm 0.50 \mathrm{~A}$ & $3.80 \pm 0.45 \mathrm{AB}$ & $0.74 \pm 0.25 \mathrm{~B}$ \\
$\mathrm{Ca}\left(\mathrm{NO}_{3}\right)_{2}$ & $479.99 \pm 62.57 \mathrm{~A}$ & $0.86 \pm 0.04 \mathrm{~A}$ & $1.56 \pm 0.44 \mathrm{~B}$ & $3.91 \pm 0.39 \mathrm{~A}$ & $1.05 \pm 0.32 \mathrm{~A}$ \\
$\mathrm{P}-\mathrm{Ca} 1500 \times$ & $489.62 \pm 38.58 \mathrm{~A}$ & $0.85 \pm 0.04 \mathrm{~A}$ & $2.20 \pm 0.44 \mathrm{~A}$ & $3.87 \pm 0.42 \mathrm{~A}$ & $0.66 \pm 0.16 \mathrm{~B}$ \\
$\mathrm{P}-\mathrm{Ca} 2500 \times$ & $484.71 \pm 50.94 \mathrm{~A}$ & $0.86 \pm 0.04 \mathrm{~A}$ & $2.81 \pm 0.47 \mathrm{~A}$ & $3.00 \pm 0.17 \mathrm{C}$ & $0.62 \pm 0.24 \mathrm{~B}$ \\
$\mathrm{P}-\mathrm{Ca} 3500 \times$ & $488.64 \pm 56.78 \mathrm{~A}$ & $0.85 \pm 0.04 \mathrm{~A}$ & $2.46 \pm 0.64 \mathrm{~A}$ & $3.56 \pm 0.31 \mathrm{AB}$ & $0.59 \pm 0.26 \mathrm{~B}$ \\
\hline
\end{tabular}

Different letters in the same column indicate significant differences by Duncan's multiple range test $(P<$ $0.01)$.

Table 5. Effects of exogenous treatments on fruit quality.

\begin{tabular}{lllll}
\hline Treatments & $\begin{array}{c}\text { Different parts } \\
\text { of fruit }\end{array}$ & $\begin{array}{c}\text { Flesh firmness } \\
\left(\mathrm{kg} \cdot \mathrm{cm}^{-2}\right)\end{array}$ & $\begin{array}{c}\text { Total soluble } \\
\text { solids }\left({ }^{\circ} \text { Brix }\right)\end{array}$ & $\begin{array}{c}\text { Titratable } \\
\text { acidity (\%) }\end{array}$ \\
\hline Control & Stem end & $8.56 \pm 0.94 \mathrm{CDEFG}$ & $13.52 \pm 0.31 \mathrm{CDEF}$ & $0.89 \pm 0.02 \mathrm{~A}$ \\
& Middle & $9.17 \pm 0.75 \mathrm{BCD}$ & $13.91 \pm 0.40 \mathrm{CDE}$ & $0.89 \pm 0.01 \mathrm{~A}$ \\
& Calyx end & $9.26 \pm 0.96 \mathrm{ABCD}$ & $13.47 \pm 0.28 \mathrm{DEF}$ & $0.81 \pm 0.12 \mathrm{AB}$ \\
$\mathrm{H}_{3} \mathrm{BO}_{3}$ & Stem end & $8.03 \pm 1.00 \mathrm{DEFG}$ & $12.73 \pm 0.83 \mathrm{~F}$ & $0.45 \pm 0.01 \mathrm{D}$ \\
& Middle & $8.46 \pm 0.83 \mathrm{CDEFG}$ & $13.53 \pm 1.03 \mathrm{CDEF}$ & $0.53 \pm 0.13 \mathrm{CD}$ \\
& Calyx end & $8.90 \pm 1.10 \mathrm{BCDE}$ & $12.92 \pm 0.75 \mathrm{EF}$ & $0.67 \pm 0.24 \mathrm{BC}$ \\
$\mathrm{Ca}\left(\mathrm{NO}_{3}\right)_{2}$ & Stem end & $10.55 \pm 1.00 \mathrm{~A}$ & $14.31 \pm 0.55 \mathrm{CD}$ & $0.45 \pm 0.02 \mathrm{D}$ \\
& Middle & $10.03 \pm 0.83 \mathrm{AB}$ & $14.41 \pm 0.88 \mathrm{CD}$ & $0.45 \pm 0.00 \mathrm{D}$ \\
$\mathrm{P}-\mathrm{Ca} 1500 \times$ & Calyx end & $9.96 \pm 1.10 \mathrm{AB}$ & $14.66 \pm 0.77 \mathrm{CD}$ & $0.44 \pm 0.02 \mathrm{D}$ \\
& Stem end & $9.35 \pm 0.93 \mathrm{ABCD}$ & $13.43 \pm 1.17 \mathrm{DEF}$ & $0.89 \pm 0.02 \mathrm{~A}$ \\
& Middle & $9.53 \pm 1.28 \mathrm{ABC}$ & $14.02 \pm 1.08 \mathrm{CDE}$ & $0.88 \pm 0.00 \mathrm{~A}$ \\
$\mathrm{P}-\mathrm{Ca} 2500 \times$ & Calyx end & $10.01 \pm 0.94 \mathrm{AB}$ & $14.11 \pm 0.83 \mathrm{CD}$ & $0.89 \pm 0.01 \mathrm{~A}$ \\
& Stem end & $7.60 \pm 0.79 \mathrm{EFG}$ & $15.48 \pm 0.46 \mathrm{AB}$ & $0.88 \pm 0.01 \mathrm{~A}$ \\
& Middle & $7.49 \pm 0.82 \mathrm{FG}$ & $15.70 \pm 0.46 \mathrm{AB}$ & $0.89 \pm 0.00 \mathrm{~A}$ \\
$\mathrm{P}-\mathrm{Ca} 3500 \times$ & Calyx end & $7.35 \pm 0.90 \mathrm{G}$ & $16.12 \pm 0.56 \mathrm{~A}$ & $0.88 \pm 0.03 \mathrm{~A}$ \\
& Stem end & $9.44 \pm 0.92 \mathrm{ABC}$ & $13.42 \pm 0.97 \mathrm{DEF}$ & $0.90 \pm 0.01 \mathrm{~A}$ \\
& Middle & $8.70 \pm 0.94 \mathrm{BCDEF}$ & $13.66 \pm 1.12 \mathrm{CDEF}$ & $0.90 \pm 0.02 \mathrm{~A}$ \\
& Calyx end & $8.58 \pm 1.09 \mathrm{CDEFG}$ & $13.91 \pm 1.25 \mathrm{CDE}$ & $0.89 \pm 0.01 \mathrm{~A}$ \\
\hline
\end{tabular}

Different letters in the same column indicate significant differences using Duncan's multiple range test at the $1 \%$ level.

increased the diameter and shortened the fruit pedicels, $\mathrm{H}_{3} \mathrm{BO}_{3}$ promoted the diameter increment of fruit pedicels, and $\mathrm{P}-\mathrm{Ca}$ at different rates decreased the calyx concave depth (Table 5). Moreover, spraying of $\mathrm{Ca}\left(\mathrm{NO}_{3}\right)_{2}$ and $\mathrm{H}_{3} \mathrm{BO}_{3}$ solutions significantly reduced the titratable acidity, resulting in improved fruit flavor. For soluble solids, P-Ca with 1500 or 3500 times dilution did not differ from control (Table 5), which agrees with those found for 'Rosemarie', 'Forelle', 'Packham's Triumph', and 'Le Conte' pear (Carra et al., 2016; Smit et al., 2005). P-Ca with 2500 times dilution significantly decreased fruit firmness and improved total soluble solids in the middle and the calyx of fruit (Table 5). To sum up, five sprays of P-Ca with 3500 times dilution was promise for inhibiting the incidence of cork spot without affecting fruit quality attributes, and could be used widely in 'Akizuki' pear cultivation.

\section{Conclusions}

Compared with normal 'Akizuki' pear fruit, cork spotted fruit had significantly larger 
fruit size with shorter fruit pedicels. Furthermore, higher levels of $\mathrm{N}, \mathrm{Ca}$, and $\mathrm{Mg}$, and lower ratios of $\mathrm{K} / \mathrm{Ca}, \mathrm{Mg} / \mathrm{Ca}$, and $(\mathrm{K}+\mathrm{Mg}) / \mathrm{Ca}$ were correlated with cork spot in 'Akizuki' pear fruit. Moreover, localization of free $\mathrm{Ca}^{2+}$ mainly in the cell wall and intercellular space may be strongly correlated with cork spot. Five sprays of P-Ca with 3500 times dilution at 15-d intervals from 30 to 90 DAFB showed promise for reducing cork spot incidence in 'Akizuki' pear without affecting fruit quality attributes. However, the mechanism of cork spot is complex and there are still many unclear details; therefore, further studies are needed focus on the relationship between cork spot and influence factors such as cultivar, climatic and soil conditions, and cultural practices including orchard fertilizer practices, excessive pruning, and poor rootstocks.

\section{Literature Cited}

Al-Ani, A.M. 1978. Postharvest physiology of 'Anjou' pear fruit: Relations between mineral nutrition and corkspot, respiration, and ethylene evolution. Oregon State University, Corvallis, PhD Diss.

Asín, L., S. Alegre, and R. Montserrat. 2007. Effect of paclobutrazol, prohexadione-Ca, deficit irrigation, summer pruning and root pruning on shoot growth, yield, and return bloom, in a 'Blanquilla' pear orchard. Scientia Hort. 113:142-148.

Askew, H.O., E.T. Chittenden, R.J. Monk, and J. Watson. 1960. Chemical investigations on bitter pit of apples. N.Z. J. Agr. Res. 3(1): 169-178.

Bangerth, F. 1974. Antagonism between calcium and other elements in the apple fruit. Acta Hort. (45):49-52.

Bar-Tal, A., B. Aloni, L. Karni, J. Oserovitz, A. Hazan, M. Itach, S. Gantz, A. Avidan, I. Posalski, N. Tratkovski, and R. Rosenberg. 2001. Nitrogen nutrition of greenhouse pepper. I. Effects of nitrogen concentration and $\mathrm{NO}_{3}$ : $\mathrm{NH}_{4}$ ratio on yield, fruit shape, and the incidence of blossom-end rot in relation to plant mineral composition. HortScience 36:12441251.

Carra, B., M.S. Pasa, J.C. Fachinello, D. Spagnol, E.S. Abreu, and M.A. Giovanaz. 2016. Prohexadione calcium affects shoot growth, but not yield components, of 'le conte' pear in warm-winter climate conditions. Scientia Hort. 209:241-248.

Costa, G., C. Andreotti, F. Bucchi, E. Sabatini, C. Bazzi, and S. Malaguti. 2001. Prohexadione-Ca (Apogee $\left.{ }^{\circledR}\right)$ : Growth regulation and reduced fire blight incidence in pear. HortScience 36:931-933.

Costa, G., E. Sabatini, F. Spinelli, C. Andreotti, G. Spada, and F. Mazzini. 2004. Prohexadione-Ca controls performance in pear vegetative growth and cropping performance in pear. Acta Hort. 653:127-132.

Dong, Y., J.F. Guan, S.J. Ma, L.L. Liu, Y.X. Feng, and Y.D. Cheng. 2015. Calcium content and its correlated distribution with skin browning spot in bagged huangguan pear. Protoplasma 252:165-171.

Dris, R., R. Niskanen, and E. Fallahi. 1998. Nitrogen and calcium nutrition and fruit quality of commercial apple cultivars grown in Finland. J. Plant Nutr. 21:2389-2402.
Einhorn, T., M. Pasa, and J. Turner. 2014. 'D'Anjou' pear shoot growth and return bloom, but not fruit size, are reduced by prohexadione-calcium. HortScience 49:180187.

Elfving, D.C., L. Lombardini, J.R. McFerson, S.R Drake, D.F. Faubion, T.D. Auvil, G. Van Ee, and D.B. Visser. 2003. Effects of directed applications of prohexadione-calcium to tops of mature pear trees on shoot growth, light penetration, pruning and fruit quality. J. Amer. Pomol. Soc. 57:45-57.

Evans, J.R., R.R. Evans, C.L. Regusci, and W. Rademacher. 1999. Mode of action, metabolism, and uptake of BAS $125 \mathrm{~W}$, prohexadione-calcium. HortScience 34:1200-1201.

Facteau, T.J., H. Cahn, and E.A. Mielke. 2010. Mineral concentrations in individual ' $d$ 'Anjou' pear fruit with and without corkspot. J. Food Qual. 23(5):513-519.

Faust, M. and C.B. Shear. 1968. Corking disorders of apples: A physiological and biochemical review. Bot. Rev. 34:441-469.

Faust, M. and C.B. Shear. 1969. Biochemical changes during the development of cork spot of apples. Qual. Plant. Mater. Veg. 19(1-3):255265.

Ferguson, I.B. and C.B. Watkins. 2011. Bitter pit in apple fruit. Hort. Rev. 11:289-355.

Freitas, S.T.D., C.V.T.D. Amarante, J.M. Labavith, and E.J. Mitcham. 2010. Cellular approach to understand bitter pit development in apple fruit. Postharvest Biol. Technol. 57:6-13.

Hawerroth, F.J., J.L. Petri, J.C. Fachinello, and F.G. Herter. 2012. Reduction of winter pruning and fruit production increase in 'Hosui' pears by prohexadione calcium use. Pesqui. Agropecu. Bras. 47:939-947.

Hayama, H., N. Mitani, T. Yamane, H. Inoue, and S. Kusaba. 2017. Characteristics of cork spot like disorder in Japanese pear 'Akizuki' and 'Oushuu'. Hort. Res. (Japan) 16(1):79-87.

Ho, L.C., D.J. Hand, and M. Fussell. 1999. Improvement of tomato fruit quality by calcium nutrition. Acta Hort. 481:463-468.

Inomata, Y., S. Murase, M. Nagara, T. Shinokawa, S. Oikawa, and K. Suzuki. 1993. Studies on factors which educe watercore in Japanese pear (Pyrus pyrifolia Nakai cv. Hosui). Engei Gakkai Zasshi 62(62):257-266.

Lanauskas, J. and N. Kviklienè. 2006. Effect of calcium foliar application on some fruit quality characteristics of 'Sinap Orlovskij' apple. Agron. Res. (Tartu) 4:31-36.

Lee, S.H., J.H. Choi, W.S. Kim, Y.S. Park, and H. Gemma. 2007. Effects of calcium chloride spray on peroxidase activity and stone cell development in pear fruit (Pyrus pyrifolia 'Niitaka'). J. Jpn. Soc. Hort. Sci. 76:191196.

Li, S.J., T.J. Facteau, P.M. Chen, and E.A. Mielke. 1999. Comparison of amylase activity and starch content in normal and cork spotted 'd 'anjou' pears. J. Food Biochem. 23(5):509518.

Lu, G., Z. Li, X. Zhang, R. Wang, and S. Yang. 2014. Expression analysis of lignin-associated genes in hard end pear (Pyrus pyrifolia Whangkeumbae) and its response to calcium chloride treatment conditions. J. Plant Growth Regulat. 34(2):251-262.

Mason, J.L. and M.F. Welsh. 1970. Cork spot (pit) of 'Anjou' pear related to calcium concentration in fruit. HortScience 5:447.

Matsumoto, K., T. Kobayashi, T. Kougo, T. Fujita, S. Sato, and T. Moriguchi. 2018. Prevention of new cork spot-like physiological disorder in 'Kurenainoyume' apples by pre-harvest fruit bagging. Hort. J. 87(2):174183.

Miqueloto, A., C.A. Steffens, A.D. Santos, and E. Mitcham. 2014. Relationship between xylem functionality, calcium content and the incidence of bitter pit in apple fruit. Scientia Hort. 165:319323.

Owens, C.L. and E. Stover. 1999. Vegetative growth and flowering of young apple trees in response to prohexadione-calcium. HortScience 34:1997-1999.

Pasa, M.S. and T.C. Einhorn. 2014. Heading cuts and prohexadione-calcium affect the growth and development of 'd'Anjou' pear shoots in a high-density orchard. Scientia Hort. 168:267271.

Qu, H.Y., X. Jiang, Z. Shi, L. Liu, and S. Zhang. 2012. Fast loading ester fluorescent $\mathrm{Ca}^{2+}$ and $\mathrm{pH}$ indicators into pollen of Pyrus pyrifolia. J. Plant Res. 125:185-195.

Rademacher, W., K. Saarloos, J.A.G. Van Porte, F.R. Forcades, Y. Senechal, C. Andreotti, F. Spinelli, E. Sabatini, and G. Costa. 2004. Impact of prohexadione-ca on the vegetative and reproductive performance of apple and pear trees. Eur. J. Hort. Sci. 69:221-228.

Raese, J.T. 1988. Calcium sprays and fertilizers found effective against 'd'Anjou' pears disorders. Good Fruit Grower 39:35-39.

Raese, J.T. 1989. Physiological disorders and maladies of pear fruit. Hort. Rev. 11:357-411.

Raese, J.T. and S.R. Drake. 1993. Effects of preharvest calcium sprays on apple and pear quality. J. Plant Nutr. 16(9):1807-1819.

Raese, J.T. and S.R. Drake. 1995. Calcium sprays and timing affect fruit calcium concentrations, yield, fruit weight, and cork spot of 'Anjou' pears. HortScience 30(5):1037-1039.

Raese, J.T. and S.R. Drake. 2006. Calcium foliar sprays for control of alfalfa greening, cork spot, and hard end in 'Anjou' pears. J. Plant Nutr. 29(3):543-552.

Raese, J.T. and D.C. Staiff. 1990. Fruit calcium, quality and disorders of apples (Malus domestica) and pears (Pyrus communis) influenced by fertilizers, p. 619-624. In: M.L. Van Beusichem (ed.). Plant nutrition-physiology applications. Kluwer, Dordrecht, The Netherlands.

Richardson, D.G. and A.M. Al-Ani. 1982. Cork spot of d'Anjou pear fruit relative to critical calcium concentration and other minerals. Acta Hort. 124:895-905.

Richardson, D.G. and P.B. Lombard. 1979. Cork spot of anjou pear: Control by calcium sprays. Commun. Soil Sci. Plan. 10(1-2):383-389.

Römmelt, S., D. Treutter, W. Rademacher, and J.B. Speakman. 1999. Effects of prohexadione$\mathrm{Ca}$ on the flavonoid metabolism of apple with respect to plant resistance against fire blight. Acta Hort. 489:359-365.

Saure, M.C. 2001. Blossom-end rot of tomato (Lycopersicon esculentum Mill.): A calciumor a stress-related disorder. Scientia Hort. 90:193-208.

Schönherr, J. and M.J. Bukovac. 1973. Ion exchange properties of isolated tomato fruit cuticular membrane: Exchange capacity, nature of fixed charges and cation selectivity. Planta 109:73-93.

Schumacher, R. and F. Fankhauser. 1970. Stippe und ihre Bekampfung. Schweiz Z ObstWeinbau 106:264-268.

Shear, C.B. 1971. Symptoms of calcium deficiency on leaves and fruits of 'York Imperial' apple. J. Amer. Soc. Hort. Sci. 96:415-417.

Smit, M., J.J. Meintjes, G. Jacobs, P.J.C. Stassen, and K.I. Theron. 2005. Shoot growth control of 
pear trees (Pyrus communis L.) with prohexadione-calcium. Scientia Hort. 106:515-529.

Sugar, D., D.C. Elfving, and E.A. Mielke. 2004. Effects of prohexadione-calcium on fruit size and return bloom in pear. HortScience 39:13051308.

Tamura, F. 2017. Occurrence of physiological disorders in Japanese pear fruit and advances in research on these disorders. Hortic. Res. (Japan) 16(4):373-381.
Tomala, K. and M. Trzak. 1994. Occurrence of cork spot (pit) in 'Alexander Lucas' pears depends on fruit mineral element content. Acta Hort. 368:570-577.

Vang-Petersen, O. 1980. Calcium nutrition of apple trees: A review. Scientia Hort. 12:1-9.

Wang, Y.L., X.F. Zhang, Y.Z. Wang, S.L. Yang, and H.Y. Qu. 2018. The changes of intracellular calcium concentration and distribution in the hard end pear (Pyrus pyrifolia cv.
'Whangkeumbae') fruit. Cell Calcium 71:1523.

Woodbridge, C.G. 1971. Calcium level of pear tissues affected with cork and black end. HortScience 6:451-453.

Yermiyahu, U., S. Nir, G. Ben-Hayyim, and U. Kafkafi. 1994. Quantitative competition of calcium with sodium or magnesium for sorption sites on plasma membrane vesicles of melon (Cucumis melo L.) root cells. J. Membr. Biol. 138:55-63. 